\title{
Implementasi Pembelajaran Sinkronus pada Mata Kuliah Fisika 1 Menggunakan Discord Dipadukan dengan Google Jamboard dan Powerpoint
}

\author{
S. Gideon* dan A. A. Rahmansyah \\ Politeknik Teknologi Kimia Industri Medan, Indonesia \\ *Email: samuel_gideon@ptki.ac.id
}

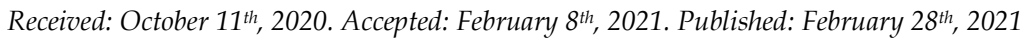

\begin{abstract}
Abstrak
Kondisi pandemi COVID-19 memaksa kegiatan belajarmengajar harus dilaksanakan melalui Pembelajaran Jarak Jauh (PJJ) online. PJJ online dapat dilakukan melalui metode sinkronus dengan salah satu alternatif penunjangnya adalah aplikasi Discord dan Google Jamboard. Tujuan dari penelitian ini adalah mengimplementasikan PJJ online mata kuliah Fisika 1 dengan menggunakan Discord yang dipadukan dengan Google Jamboard dan Powerpoint. Metode penelitian yang digunakan adalah penelitian deskriptif dalam beberapa tahap, yaitu: (1) instalasi dan menyiapkan Ruang Kelas Fisika 1 di aplikasi Discord; (2) instalasi dan uji coba aplikasi Virtual Tablet Server di handphone; (3) menyiapkan materi pembelajaran dalam bentuk file Powerpoint; (4) implementasi pembelajaran Fisika 1 menggunakan Discord dipadukan Google Jamboard serta Powerpoint; (5) evaluasi dan analisis hasil implementasi serta (6) survei untuk memperoleh informasi berbentuk opini terkait PJJ online yang dilaksanakan. Discord dapat digunakan sebagai alternatif PJJ online karena pengunaannya yang praktis lebih ramah kuota internet dan akan semakin baik jika dipadukan dengan aplikasi Google Jamboard dan Powerpoint, sehingga dapat mengakomodir mata-mata kuliah yang membutuhkan penjelasan yang bersifat matematis seperti Fisika. Hal tersebut didukung dengan hasil survei, 34 dari 39 mahasiswa menyatakan ingin menggunakan Discord dan Google Jamboard untuk mata kuliah yang membutuhkan penjelasan yang bersifat matematis lainnya.
\end{abstract}




\begin{abstract}
COVID-19 virus have affected educational activities to be carried out through e-learning. Discord and Google Jamboard offer advantages in delivering synchronous e-learning. The purpose of this research is to implement e-learning of Physics 1 course using Discord integrated with Google Jamboard and Powerpoint. In this research, we used qualitative-descriptive method which conducted in several steps, i.e: (1) Discord installation and Physics 1 Class preparation; (2) Virtual Tablet Server installation and its testing for mobile phone; (3) Learning materials preparation in Powerpoint; (4) Implementation of Physics 1 Class using Discord integrated with Google Jamboard and Powerpoint; (5) Evaluation of the results and (6) Surveying of student's opinion about e-learning using using Discord integrated with Google Jamboard and Powerpoint. Discord can be used as an alternative e-learning tool because of its practical use as well as more powerful when integrated with Google Jamboard and Powerpoint, especially for mathematicalanalytics subject such as Physics. This is supported by the results of a survey in which 34 out of 39 students said they wanted to use Discord and Google Jamboard for other mathematical-analytics subjects. @2021PERJ
\end{abstract}

Keywords: Discord; E-learning; Google Jamboard; Powerpoint.

\section{PENDAHULUAN}

Kondisi pandemi COVID-19 yang sedang melanda saat ini menimbulkan permasalahan tersendiri di dalam proses pelaksanaan pembelajaran. Kegiatan belajar mengajar yang sebelumnya dilaksanakan secara tatap muka, kini mau tidak mau harus dilaksanakan melalui suatu pembelajaran jarak jauh (PJJ) secara daring atau online (Firman \& Rahman, 2020). PJJ online tidak kalah efektif jika dibandingkan dengan tatap muka karena dalam PJJ online antara pengajar dan peserta didik dapat berinteraksi secara langsung (sinkronus) (Pakpahan \& Fitriani, 2020) dengan fitur video/audio conference ataupun pesan singkat (chat) (Budiyanto \& Pujiyono, 2014).

PJJ online dapat dilakukan melalui metode sinkronus. Pada metode sinkronus, pendidik dan peserta didik dapat saling berdiskusi seperti pertemuan tatap muka di kelas (Simarmata, 2018). Aplikasi yang banyak digunakan untuk menunjang PJJ online secara sinkronus antara lain adalah Zoom. Data terkini menunjukkan bahwa pengguna Zoom per harinya mencapai 300 juta (Fuadi, 
Musriandi, \& Suryani, 2020). Putra \& Nisaurrasyidah memanfaatkan fitur video conference dari Zoom sebagai penunjang PJJ online. Zoom juga digunakan untuk mata kuliah yang melibatkan perhitungan seperti Statistik Pendidikan (Rosyid, Thohari, \& Lismanda, 2020).

Selain Zoom, media PJJ online sinkronus lain yang dapat digunakan adalah Discord, yang merupakan sarana komunikasi audio dengan mahasiswa. Pada aplikasi Discord yang terdengar hanya suara, namun wajah dosen maupun mahasiswa tidak terlihat secara live. Aplikasi Discord telah digunakan oleh pendidik untuk pelaksanaan PJJ online. Seto (2020) menggunakan aplikasi Discord sebagai alternatif PJJ online selain Zoom yang digabungkan dengan Microsoft Powerpoint 365; sedangkan Ikhwanuddin (2020) menggunakan Discord sebagai alternatif PJJ online selain Zoom yang digabungkan dengan aplikasi Keynote Live.

Penelitian mengenai penggunaan Discord sebagai penunjang PJJ online juga dilakukan oleh pendidik di Ukraina. Kruglyk, Bukreiev, Chornyi, Kupchak, \& Sender (2020) memanfaatkan Discord selama situasi darurat belajar akibat pandemi Covid-19. Lacher \& Biehl (2019) mengungkapkan bahwa Discord yang awalnya digunakan sebagai aplikasi untuk para online gamer, ternyata menjadi sarana efektif bagi pendidik untuk melibatkan peserta didik dalam tugas-tugas yang membutuhkan kerjasama tim. Penelitian tentang penggunaan aplikasi Discord di Indonesia juga telah dilakukan oleh Dewantara, Efriani, \& Afandi (2020), yang menggunakan Discord sebagai penunjang PJJ online untuk mata kuliah Pendidikan Pancasila dan Kewarganegaraan serta Kedokteran Umum.

Dewantara (2020), Rosyid, Thohari, \& Lismanda (2020), Seto (2020) maupun Ikhwanuddin (2020) melewatkan satu permasalahan, yaitu tidak mempertimbangkan bagaimana melakukan penyelesaian soal perhitungan seperti fisika ataupun matematika. Sebuah aplikasi bernama Google Jamboard memberikan akses terbuka dalam menangani permasalahan tersebut. Basilaia, Chokhonelidze, Dgebuadze, \& Kantaria (2020) menggambarkan secara singkat aplikasi tersebut seperti papan tulis digital interaktif, yang diciptakan oleh Google. Aplikasi tersebut telah tersedia dan langsung dapat digunakan ketika seseorang sudah memiliki akun Gmail. Tujuan penelitian ini adalah menguji implementasi PJJ online mata kuliah Fisika 1 dengan menggunakan Discord yang dipadukan dengan Google Jamboard dan Microsoft Powerpoint.

\section{METODE}

Metode penelitian yang digunakan adalah deskriptif 
kualitatif yang didukung dengan penelitian survei. Observasi langsung dilakukan untuk mengamati seluruh peristiwa yang terjadi pada saat melakukan PJJ online Fisika 1 pada mahasiswa Teknik Kimia Politeknik Teknologi Kimia Industri (PTKI) Medan tahun ajaran 2019/2020 yang berjumlah 39 orang. Instrumen yang digunakan berupa angket survei yang diisi secara online menggunakan aplikasi FormApps, dengan pertanyaan yang diajukan dalam survei mengenai pernah atau tidaknya mahasiswa menggunakan Discord dan Google Jamboard di mata kuliah lain, kenyamanan mahasiswa menggunakan

Discord dibandingkan Zoom, kendala yang ditemui selama menggunakan Discord dan Google Jamboard serta apakah mahasiswa masih tertarik menggunakan Discord dan Jamboard untuk mata kuliah yang membutuhkan penjelasan yang bersifat matematis lainnya.

Aplikasi/perangkat (software) yang digunakan dalam penelitian ini adalah Discord, Virtual Tablet Server, Google Jamboard dan Microsoft Powerpoint 2016. Perangkat keras (hardware) yang digunakan dalam penelitian ini adalah laptop ASUS Vivobook 14 dan handphone Samsung Galaxy Note 10 yang dilengkapi stylus pen.

Penelitian ini dilakukan dalam enam tahap, yaitu: (1) instalasi dan menyiapkan Ruang Kelas Fisika 1 di aplikasi Discord; (2) instalasi dan uji coba aplikasi Virtual Tablet Server di handphone; (3) menyiapkan materi pembelajaran dalam bentuk file Powerpoint; pembelajaran (4) implementasi Fisika 1 menggunakan Discord dipadukan Google Jamboard serta Powerpoint; (5) evaluasi dan analisis hasil implementasi serta (6) survei untuk memperoleh informasi berbentuk opini terkait PJJ online yang dilaksanakan. Instalasi aplikasi Discord dilakukan dengan mengunduh terlebih dahulu melalui situs discord.com (karena laptop yang digunakan menggunakan sistem operasi Windows, dipilih unduhan untuk sistem operasi tersebut). Setelah meng-install aplikasi Discord di laptop selanjutnya dipastikan mahasiswa telah meng-install juga di laptop ataupun handphone masing-masing melalui grup Whatsapp mahasiswa Teknik Kimia TA. 19/20. Video penggunaan Discord diunduh dari Youtube untuk dibagikan di grup Whatsapp mahasiswa Teknik Kimia TA. 19/20.

\section{HASIL DAN PEMBAHASAN}

Persiapan Ruang Kelas Fisika 1 Teknik Kimia TA 19/20 di aplikasi Discord dilakukan melalui pengaturan server secara umum, yaitu memberi nama Samuel Gideon, M.Si selaku dosen pembimbing sekaligus memberi ikon server yang sudah didesain sebelumnya menggunakan aplikasi Canva dan bertuliskan Fisika 1. 
Selanjutnya yaitu pengaturan roles yang terdiri atas "Dosen" dan "Mahasiswa Teknik Kimia". Pengaturan fitur-fitur lain juga diperlukan untuk proses PJJ online di dalam Discord mulai dari send messages sampai push to talk. Terakhir adalah membuat text chat channel dan voice chat channel. Text chat channel diberi nama "fisika1_tk_ta19_20", sementara voice chat channel diberi nama "FISIKA 1 T.KIMIA (TA 19/20)". Hasil dari pembuatan Ruang Kelas Fisika 1 ditunjukkan pada Gambar 1.

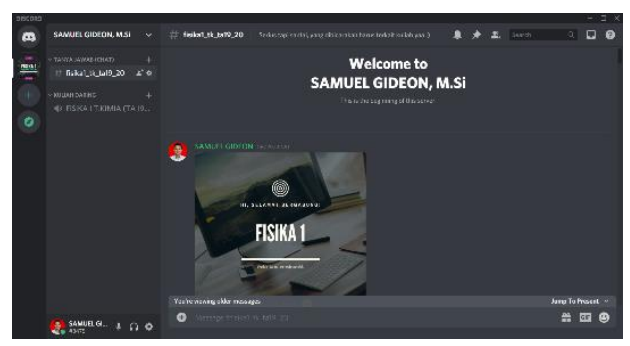

Gambar 1. Ruang Kelas Fisika 1

Instalasi aplikasi Virtual Tablet Server dilakukan dengan mengunduh melalui Playstore di handphone (karena handphone yang digunakan dalam penelitian memiliki sistem operasi android). Setelah diunduh, pengaturan selanjutnya terkait dengan usb debugging di handphone agar aplikasi tersebut dapat tersambung sekaligus berjalan dengan baik di laptop. Tampilan konfigurasi virtual Tablet Server di laptop ditunjukkan pada Gambar 2 dan tampilan papan tulis virtual yang terlihat di handphone ditunjukkan pada Gambar 3.

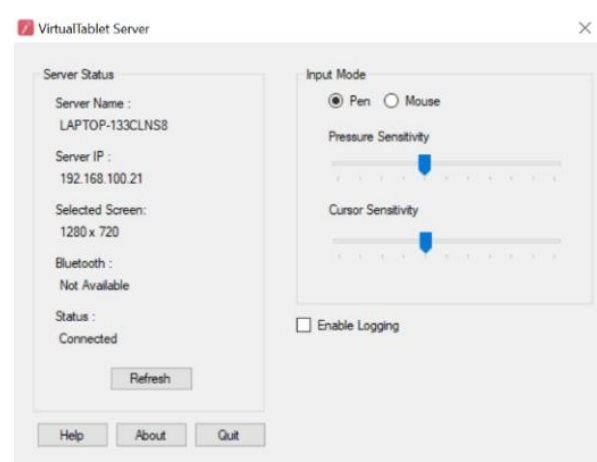

Gambar 2. Tampilan Konfigurasi Virtual Tablet Server di Laptop

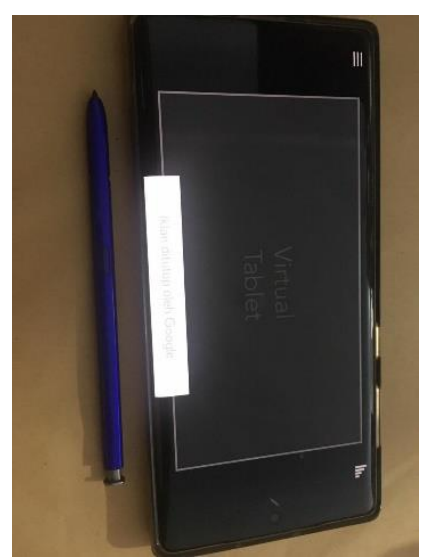

Gambar 3. Tampilan Papan Tulis Virtual di Handphone Dan Sylus Pen Yang Digunakan.

Materi pembelajaran Fisika 1 dibuat dalam bentuk file Powerpoint dengan menggunakan Microsoft Powerpoint 2016. Topik-topik yang diangkat menjadi materi adalah Konsep Dasar Fisika dan Pengantar Vektor, Kinematika Gerak, Dinamika Gerak, Fluida serta Suhu dan Kalor. Masing-masing topik tersebut dibuat dalam satu file Powerpoint. Pada awal implementasi PJJ online, link Ruang Kelas Fisika 1 Teknik Kimia TA 
19/20 dibagikan melalui grup Whatsapp sekaligus ujicoba untuk mengobrol dan saling berkirim teks dengan mahasiswa pada text chat channel "fisika1_tk_ta19_20" dan voice chat channel "FISIKA 1 T.KIMIA (TA 19/20)".

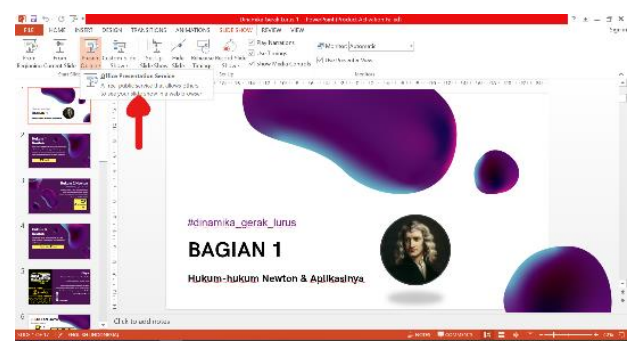

Gambar 4. Salah Satu Slide Powerpoint (Tanda Panah Merah Menunjukkan Fitur untuk Presentasi Live)

Pada pertemuan selanjutnya, link Powerpoint yang telah dibuat kemudian dibagikan ke mahasiswa melalui text chat Discord. Link Powerpoint dapat dibuat dengan cara mengklik tombol "Present Online" pada menu "Slide Show" di file Powerpoint yang dibuka. Ketika mahasiswa mengklik link Powerpoint tersebut, maka file Powerpoint tersebut ditampilkan secara live di laptop ataupun handphone mahasiswa. Pada saat dosen berpindah dari satu slide ke slide lain, maka perpindahan tersebut juga terjadi di laptop ataupun handphone mahasiswa. Salah satu slide dalam file Powerpoint ditunjukkan pada Gambar 4. Dosen selalu memberikan contoh soal yang melibatkan analisis dan perhitungan pada setiap file Powerpoint. Pada saat akan membahas soal, dosen membagikan link Jamboard ke mahasiswa melalui text chat Discord.

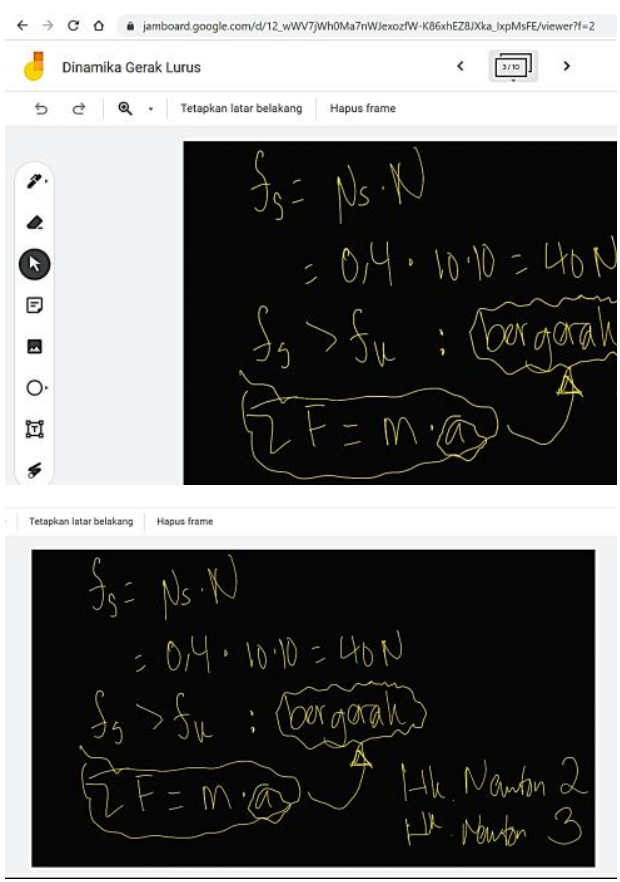

Gambar 5. Contoh Jam Google Jamboard.

Dosen menunggu beberapa saat untuk memastikan semua mahasiswa sudah mengklik link tersebut. Setelah itu, dosen menjelaskan proses analisis dan perhitungan step-by-step. Dosen menulis di layar handphone sambil memperhatikan tulisan yang muncul di laptop, yang ditampilkan secara live di laptop ataupun handphone mahasiswa. Salah satu tampilan papan tulis digital Jamboard ditunjukkan pada Gambar 5.

Pendapat mahasiswa tentang penggunaan aplikasi Discord yang dipadukan dengan Google Jamboard digali melalui survei 
kepada mahasiswa peserta kuliah Fisika 1. Hasil survei penggunaan Discord yang dipadukan dengan
Google Jamboard dapat dilihat pada Tabel 1.

Tabel 1. Hasil Survei Penggunaan Discord yang Dipadukan dengan Google Jamboard pada Mata Kuliah Fisika 1

\begin{tabular}{|c|c|}
\hline Pertanyaan & Hasil Respon \\
\hline $\begin{array}{l}\text { Selain di kuliah Fisika 1, apakah } \\
\text { kalian pernah menggunakan } \\
\text { Discord di mata kuliah lain? }\end{array}$ & $\begin{array}{l}33 \text { orang menjawab belum pernah dan } 6 \\
\text { orang menjawab sudah pernah }\end{array}$ \\
\hline $\begin{array}{l}\text { Selain di kuliah Fisika 1, apakah } \\
\text { kalian pernah menggunakan } \\
\text { Discord di mata kuliah lain? }\end{array}$ & $\begin{array}{c}37 \text { orang menjawab belum pernah dan } 2 \\
\text { orang menjawab sudah pernah }\end{array}$ \\
\hline $\begin{array}{l}\text { Mana yang lebih nyaman } \\
\text { digunakan, Discord atau Zoom? }\end{array}$ & $\begin{array}{c}18 \text { orang menjawab zoom dan } 21 \text { orang } \\
\text { menjawab discord }\end{array}$ \\
\hline $\begin{array}{l}\text { Kendala apa yang ditemui selama } \\
\text { pakai Discord? }\end{array}$ & $\begin{array}{l}5 \text { orang menjawab susah didownload, } 18 \\
\text { orang menjawab suara kurang jernih dan } 16 \\
\text { orang menjawab tidak ada }\end{array}$ \\
\hline $\begin{array}{l}\text { Kendala apa yang ditemui selama } \\
\text { menggunakan Google Jamboard? }\end{array}$ & $\begin{array}{c}12 \text { orang menjawab susah diakses, } 12 \text { orang } \\
\text { menjawab tampilannya tersendat-sendat dan } \\
15 \text { orang menjawab tidak ada }\end{array}$ \\
\hline $\begin{array}{l}\text { Apakah di mata kuliah lain } \\
\text { (khususnya yang hitung- } \\
\text { hitungan) kalian mau } \\
\text { menggunakan Discord dan } \\
\text { Google Jamboard lagi? }\end{array}$ & $\begin{array}{c}34 \text { orang menjawab mau dan } 5 \text { orang } \\
\text { menjawab tidak mau }\end{array}$ \\
\hline
\end{tabular}

Hasil observasi langsung dan implementasi Discord pada PJJ online mata kuliah Fisika 1 menunjukkan beberapa keunggulan Discord dan Google Jamboard. Keunggulan pertama adalah pendidik dapat mengatur manajemen pembelajaran online sesuai dengan yang diinginkan. Pendidik dengan leluasa dapat memberikan materi ajar (baik berupa link Powerpoint maupun link Google Jamboard) pada text chat channel "fisika1_tk_ta19_20". Keunggulan ke dua adalah peserta didik dapat mengikuti perkuliahan secara lebih fleksibel melalui voice chat channel "FISIKA 1 T.KIMIA (TA 19/20)". Mahasiswa merasa lebih nyaman serta tidak grogi dalam bertanya ataupun menjawab pertanyaan dari dosen. Selain itu, keunggulan tersebut juga sesuai dengan penelitian yang dilakukan oleh Monica \& Fitriawati (2020) yang memaparkan ketidakhadiran 
dosen secara fisik membuat mahasiswa tidak merasa canggung dalam mengemukakan pendapat. Keunggulan ke tiga adalah integrasi Discord, Google Jamboard, dan Powerpoint disukai serta diharapkan oleh mahasiswa dapat digunakan pada mata kuliah yang membutuhkan penjelasan yang bersifat matematis lainnya. Hal tersebut juga sesuai dengan penelitian yang dilakukan oleh Lacher \& Biehl (2019) yang memaparkan $68 \%$ responden sangat ingin untuk menggunakan Discord kembali dalam pembelajaran.

Hasil implementasi Discord pada PJJ online mata kuliah Fisika 1 ternyata juga menunjukkan kendala dan kelemahan Discord dan Google Jamboard. Kendala pertama adalah transisi berbicara antara dosen dengan mahasiswa agak sulit karena di Discord tidak ada fitur "Raise Hand" seperti halnya di Zoom. Oleh karena itu, pada sesi tanya jawab terjadi sedikit chaos yang menyulitkan dosen dalam mengontrol kelas. Kendala ke dua adalah suara yang kurang jernih dan

\section{KESIMPULAN}

Discord dapat digunakan sebagai alternatif PJJ online selain Zoom karena pengunaannya yang praktis dan lebih diminati siswa. Keunggulan Discord semakin baik ketika dipadukan dengan aplikasi Google Jamboard dan Powerpoint, sehingga dapat mengakomodir tampilan Google Jamboard yang tersendat-sendat karena jaringan internet yang tidak stabil. Beberapa kali dosen mengalami kesulitan menjelaskan analisis dan perhitungan Fisika kepada mahasiswa karena adanya jeda saat menulis di handphone dengan yang ditampilkan di laptop. Jeda tersebut terjadi sekitar tiga sampai lima detik. Akibatnya seringkali tulisan menjadi sedikit berantakan. Kendala terakhir adalah masalah penyimpanan di handphone. Mahasiswa memiliki handphone dengan kapasitas penyimpanan yang tidak begitu besar sementara Discord perlu diunduh. Akibatnya mahasiswa harus menghapus beberapa aplikasi agar dapat mengunduh Discord. Hal tersebut sesuai dengan hasil penelitian yang dilakukan oleh Rosyid et al. (2020) yang memaparkan bahwa tidak semua mahasiswa memiliki handphone yang memadai untuk mengikuti kuliah secara daring karena memori penyimpanan yang masih jauh dari cukup untuk ukuran smartphone masa kini.

mata kuliah yang membutuhkan penjelasan yang bersifat matematis seperti Fisika.

\section{DAFTAR PUSTAKA}

Basilaia, G., Chokhonelidze, G., Dgebuadze, M., \& Kantaria, M. 2020. Replacing the Classic Learning Form at Universities as an Immediate Response to 
the COVID-19 Virus Infection in Georgia. International Journal for Research in Applied Science and Engineering Technology, 8(3), 101-108. https://doi.org/10.22214/ijraset. 2020.3021

Budiyanto, A., \& Pujiyono, W. 2014.

Sistem Broadcast Proses

Belajar Mengajar dengan Synchronous dan

Asynchronous. Jurnal Sarjana Teknik Informatika, 2(1), 7890.

https://doi.org/10.12928/jstie.v 2i1.2605

Dewantara, J. A., Efriani, E., \& Afandi. 2020. Pemanfaatan Aplikasi Discord sebagai Media Pembelajaran Online. Jurnal Teknologi Informasi dan Pendidikan, 13(1), 61-65.

Firman, F., \& Rahman, S. R. 2020.

Pembelajaran Online di Tengah Pandemi Covid-19. Indonesian Journal of Educational Science (IJES), 2(2), 81-89.

Fuadi, T. M., Musriandi, R., \& Suryani, L. 2020. Covid-19: Penerapan Pembelajaran Pembelajaran Daring di Perguruan Tinggi. Jurnal Dedikasi Pendidikan, 8848(2), 193-200.

Ikhwanuddin, R. 2020. Kuliah Daring Tersinkron Hemat Data. Diambil 31 Maret 2020, dari Facebook.com website: https://web.facebook.com/grou ps/dosen.muda.indonesia/perm alink/2418251914943413/?_rd $\mathrm{c}=1 \& \_r d r$
Kruglyk, V., Bukreiev, D., Chornyi, P., Kupchak, E., \& Sender, A. 2020. Discord Platform as An Online Learning Environment for Emergencies. Ukrainian Journal of Educational Studies and Information Technology, $8(2), 13-28$.

Lacher, L. L., \& Biehl, C. 2019. Investigating Team Effectiveness Using Discord: A Case Study Using a Gaming Collaboration Tool for the CS Classroom. International Conference Frontiers in Education 2019: CS and CE, 15(1), 199-204.

Monica, J., \& Fitriawati, D. 2020. Efektivitas Penggunaan Aplikasi Zoom Sebagai Media Pembelajaran Online Pada Mahasiswa Saat Pandemi Covid-19. Jurnal Communio: Jurnal Jurusan Ilmu Komunikasi, 9(2), 1630-1640. https://doi.org/10.35508/jikom. v9i2.2416

Pakpahan, R., \& Fitriani, Y. 2020. Analisa Pemanfaatan Teknologi Informasi dalam Pembelajaran Jarak Jauh di Tengah Pandemi Virus Corona Covid-19. JISAMAR (Journal of Information System, Applied, Management, Accounting and Researh), 4(2), 30-36.

Putra, N. P., \& Nisaurrasyidah, I. 2020. Solusi Pembelajaran Jarak Jauh Menggunakan Aplikasi Zoom dan Whatsapp Group di Era New Normal pada Warga Belajar Paket C di 
PKBM Bina Mandiri Kota Cimahi. Prosiding Webinar Magister Pendidikan Nonformal Pascasarjana Universitas Negeri Gorontalo, (September), 19-24.

Rosyid, N. M., Thohari, I., \& Lismanda, Y. F. 2020. Penggunaan Aplikasi Zoom Cloud Meetings dalam Kuliah Statistik Pendidikan di Fakultas Agama Islam Universitas Islam Malang. VICRATINA: Jurnal Pendidikan Islam, 5(1), 1-5.

Seto, A. 2020. Live Presentation \& Audio Communication for
Online Teaching. Diambil 26 Maret 2020, dari Facebook.com website:

https://web.facebook.com/grou ps/dosen.muda.indonesia/perm alink/2409824689119469/?_rd $\mathrm{c}=1 \& \_r d r$

Simarmata, J. 2018. Teknologi Sinkronus dan Asinkronus untuk Pembelajaran. In Teknologi dan Aplikasinya dalam Dunia Pendidikan (hal. 1-56). Diambil dari http://jayapanguspress.org 
Phy. Educ. Res. J. Vol. 3 No. 1 (2021), 1-10 